\title{
NUP214 wt Allele
}

National Cancer Institute

\section{Source}

National Cancer Institute. NUP214 wt Allele. NCI Thesaurus. Code C52288.

Human NUP214 wild-type allele is located in the vicinity of 9q34.1 and is approximately $108 \mathrm{~kb}$ in length. This allele, which encodes nuclear pore complex protein Nup214, plays a role in the regulation of nucleocytoplasmic transport and receptor-mediated nuclear import. The 3 prime portion of the gene can form a fusion construct with the DEK gene on chromosome 6 in a t $(6,9)$ translocation. The translocation is associated with acute myeloid leukemia and myelodysplastic syndrome. 